\title{
Wildlife conservation problems in the Juan Fernández Archipelago, Chile
}

\author{
W. R. P. Bourne, M. de L. Brooke, G. S. Clark and T. Stone
}

The rugged islands where the original Robinson Crusoe was marooned in the south -east Pacific are remarkable for the number and variety of endemic plants, some of which are pollinated by a beautiful endemic hummingbird. They are also the main breeding station of a fur seal, which once numbered millions but was later thought to be extinct, and several widespread seabirds. So far the only losses appear to be the endemic sandalwoods and widespread elephant seal, but the other wildlife is now threatened by deforestation, erosion and competition or predation from introduced species. There is a need for more support for local conservation measures, since the islands may soon start to undergo rapid development.

The Juan Fernández archipelago (Figures 1 and 2) comprises the two exposed western summits of a chain of submarine tertiary volcanoes formed as the Nazca plate moved east over a 'hotspot'. It has a marvellous wildlife, including many ancient relicts that have shown marked local evolution (Skottsberg, 1920-1956, Stuessy et al., 1984). The main eastern island $650 \mathrm{~km}$ off Valparaiso was originally called Santa Cecilia, then Más a Tierra ('nearer the land'), and renamed Robinson Crusoe in 1966. It has one major western outlier, Santa Clara or Goat Island, and they have several smaller rock stacks offshore. The other large island lying $182 \mathrm{~km}$ further west is still often called Más Afuera ('further out'), but has also been renamed Alejandro Selkirk.

The islands were originally covered with forest of diverse origins several million years old. The Swedish Pacific Expedition of 1916/17 (Skottsberg, 1920-1956) found that at least 98 out of 142 native vascular plants are endemic, including a monotypic family, the Lactoridaceae, and various giant forms such as the 'rhubarb' Gunnera peltata, and a remarkable radiation of Compositae including 'cab. bage trees' in the genus Dendroseris. Nineteen of the 54 ferns, including another monotypic family, the Thyrsopteridaceae, 35 of the 46 molluscs (Kunkel, 1968), and 440 of the 687 insects (Kuschel, 1963) are also endemic. Three of the eight native landbirds of South American origin are endemic species, and three more land birds and two of the six seabirds with allies in the New Zealand area are endemic races. Three other seabirds and the fur seal Arctocephalus philippi only breed elsewhere on the small Desventuradas islets to the north.

The romantic history of the group is reviewed by Woodward (1969) and Arana (1985). The eastern islands were probably discovered by Juan Fernández on 22 November 1574 while pioneering a faster route south down the west coast of South America outside the northbound Humboldt Current. They were occupied briefly and various plants and animals introduced, then abandoned to the buccaneers. The most famous, Alexander Selkirk, quarrelled with his captain and was marooned on Isla Robinson Crusoe in October 1704 for four years and four months, inspiring the classic story by Daniel Defoe about a different sort of castaway on a different sort of island. Robinson Crusoe was reoccupied by the Chileans in the 1760 s, and now has a crayfishing community of about 500, of whom about 50 summer on Alejandro Selkirk.

Goats were released by the first colonists and flourished despite the introduction of 'mastiffs' to control them in the 1670s. When the goats took to the rocks the dogs turned on 
the seabirds, and only died out on Robinson Crusoe in about 1830 and on Alejandro Selkirk in about 1892. Selkirk also reported many rats and cats, which still survive on both large islands. The buccaneers were followed by sealers, who killed most of the fur seals and exterminated the elephant seals Mirounga leonina (first described from here) and an undescribed native sandalwood on Alejandro
Selkirk in the early nineteenth century. The last tree of the endemic sandalwood Santalum fernandezianum on Robinson Crusoe disappeared between 1908 and 1916 .

The entire archipelago, except the village of San Juan Bautista, was designated a Chilean National Park, mainly on botanical grounds, in 1935, then a UNESCO Biosphere Reserve in 1977 , and was included among the 11 most

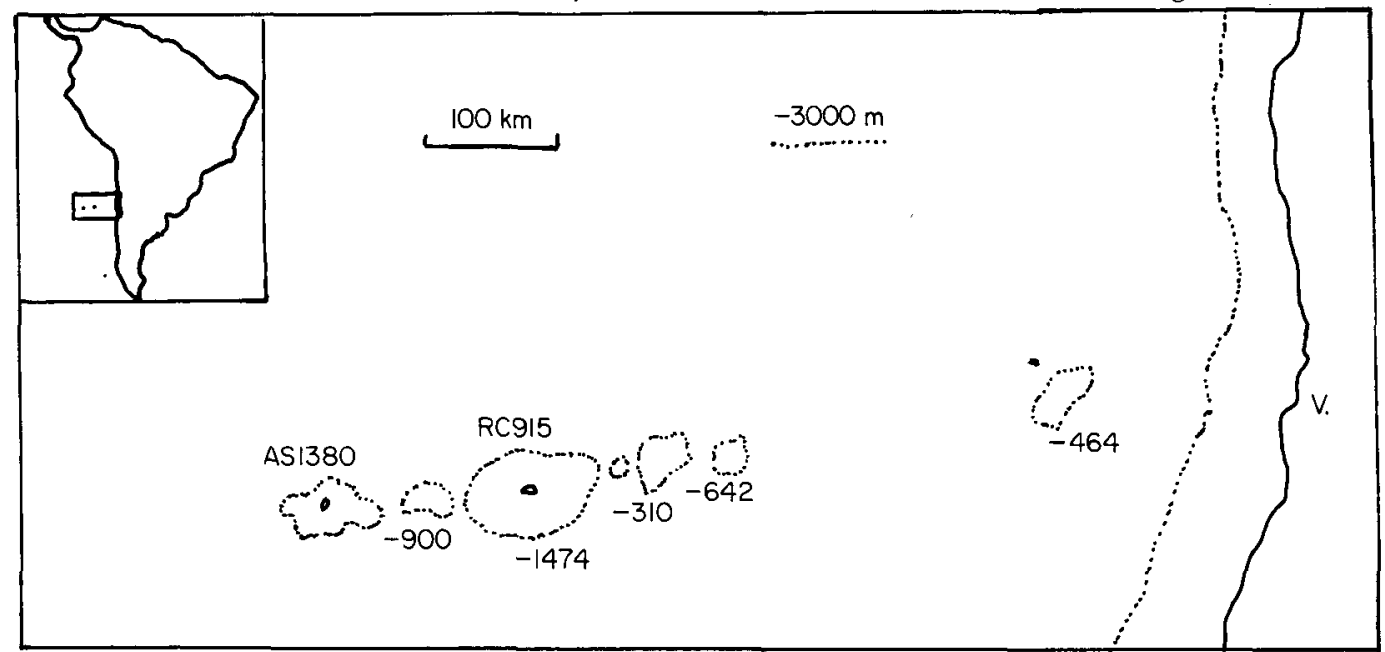

Figure 1. The altitude in metres above and below sea-level of the volcanoes on the Juan Fernández submarine ridge (derived from Stuessy et al., 1984). AS: Alejandro Selkirk, RC: Robinson Crusoe, V: Valparaiso.

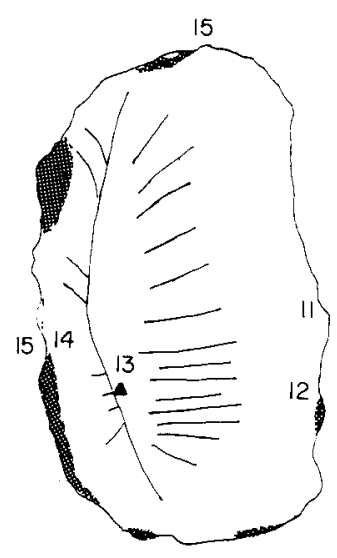

Alejandro Selkirk

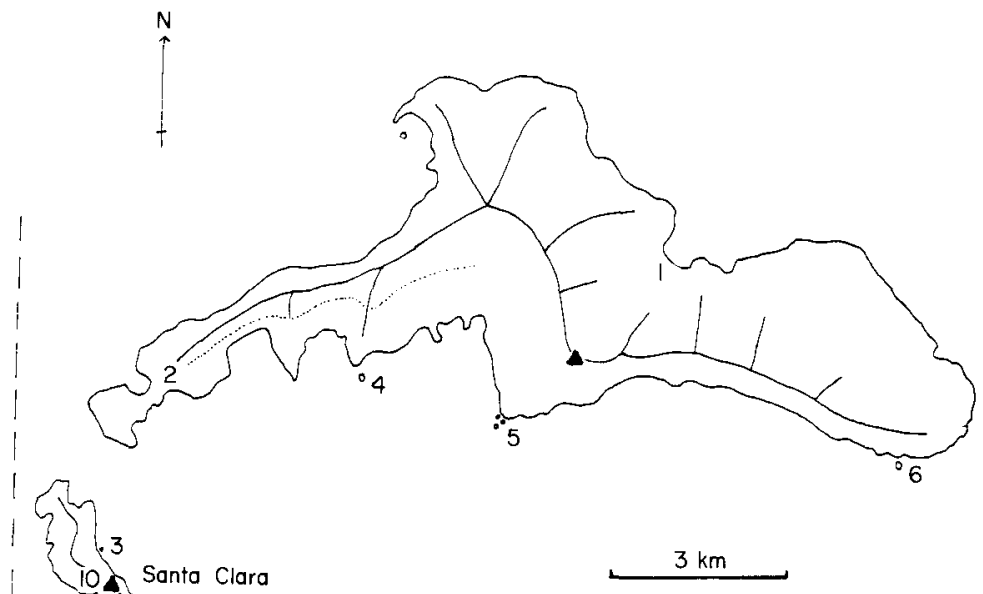

Robinson Crusoe

Figure 2. Topography of the Juan Fernández islands. 1. Village of San Juan Bautista in Cumberland Bay. 2. Airfield and unfinished road. 3. Morro Spartán. 4. Morro Viñillo. 5. Los Chamelos. 6. El Verdugo. 7. Morro Juanango. 8. The Mirador of Alejandro Selkirk. 9. El Yunque $(915 \mathrm{~m}) .10$. C. Johow $(350 \mathrm{~m})$. 11. Settlement of Las Casas. 12. Quebrada Vacas (one route is up the west ridge). 13. Los Innocentes (1380 m). 14. Quebrada Guatan (best surviving forest). 15. Impassable shore between seal nurseries (shaded). 
seriously threatened 'protected natural areas' in the world at the IUCN General Assembly in 1984 (Allen, 1984). It is now managed by the Corporacion Nacional Forestal (CONAF) with assistance from IUCN and WWF according to a plan drawn up with FAO (Anon., 1976). Since 1972 CONAF has had a permanent station in San Juan Bautista, staffed by a park warden with a 3-year term of office from the mainland, assisted by 10 local rangers (Anon., 1982).

The botany is discussed by Sandars et al. (1982) and Perry (1984). We visited all the main islands and Morros Spartán and Viñillo in May and June 1983 (Bourne 1983a,b; Clark, 1988), December 1985 to February 1986 (Brooke, 1987a,b, 1988), and September and October 1988 (Stone et al., 1990) to survey the birds (Johnson and Goodall, 1965-1972). The Alejandro Selkirk race of red-backed hawk Buteo polysoma exsul and house sparrow Passer domesticus have been introduced to Robinson
Crusoe, the Robinson Crusoe race of American kestrel Falco sparverius fernandensis has appeared, the small hummingbird has replaced the large one on Alejandro Selkirk, and the introduced Californian quail Lophortyx californica has now gone from both islands.

\section{Isla Robinson Crusoe}

The largest island consists of $93 \mathrm{sq} \mathrm{km}$ of moderately eroded basalt some 3.8-4.2 million years old lying $650 \mathrm{~km}$ west of Valparaiso. Much of the wetter eastern part of the rugged central ridge rising to the spectacular $915-\mathrm{m}$ peak of El Yunque is still clothed above $300 \mathrm{~m}$ in luxuriant native forest covered in epiphytes (Figure 3). Unfortunately, following four centuries of woodcutting and grazing by all the usual domestic animals, 39 per cent of the hanging valleys around its flanks and the low

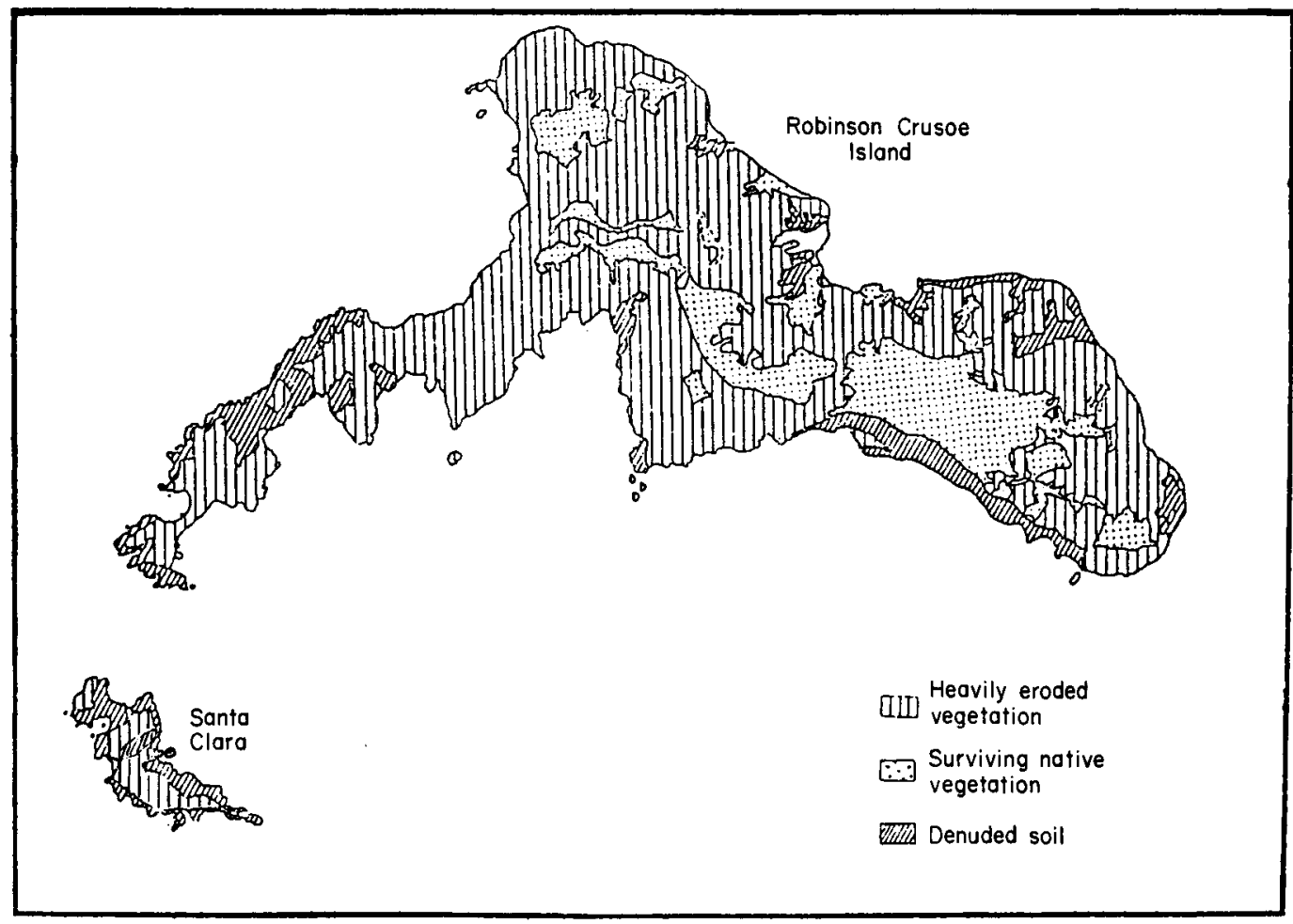

Figure 3. Levels of erosion on the main islands (derived from $\mathrm{H}$. Godoy,

Picaflor de Juan Fernández, Naturaleza 1988). 
arid western end of the island are now bare, another 14 per cent is moderately eroded, and much of the remaining low ground is smothered in a tangle of introduced plants.

Thus, although the introduction of eucalypts and conifers early in this century reduced erosion around the only settlement of San Juan Bautista, other introductions, notably the shrub 'maquis' Aristotelia chilensis, a bramble 'zarzamora' Rubus ulmifolius, and the herb 'palqui' Acaena argentea, are now rapidly expanding to displace the native vegetation. Following the creation of the National Park, the introduction of rabbits Oryctolagus cuniculus and coatis Nasua nasua by 'seudonaturalistas' to improve the wildlife (Muñoz Pizarro, 1969) also reinforced the impact of the longestablished house mouse Mus musculus, black and brown rats, Rattus rattus and $R$. norvegicus, and feral cats Felis domestica on the native community.

Measures are now being taken to deal with the situation. The sheep were removed in 1983, and there are now only about 300 multicoloured goats left in the cliffs. Plans to reduce the cattle to a small dairy herd are frustrated by a lack of funds to pay compensation. One ranger is already catching 1000 rabbits a month with little effect on a population once estimated at 52,000 (Saiz, 1982), and other means of reducing them, such as myxomatosis, may need consideration. Fungal control of the bramble has been successful in greenhouse tests (Oehrens and Garrido, 1985). CONAF has been propagating the native plants for some years, with assistance since 1988 from WWF-US, and commissioned an aerial survey of the vegetation in 1989.

\section{Isla Santa Clara and other outliers}

Santa Clara is an arid eroding islet $5 \mathrm{sq} \mathrm{km}$ in area and $350 \mathrm{~m}$ high lying $1 \mathrm{~km}$ south-west of Robinson Crusoe, which appears to be the oldest (and therefore most extensively eroded) part of the archipelago, with an age of c. 5.8 million years. There is no water so that it is uninhabited by man, but for a long time there were many goats, with at least one surviving in 1988, and there are now also many black or rufous rabbits. The native vegetation has been almost entirely destroyed, and the upper slopes are now covered in Avena barbata grassland surrounded by crumbling cliffs and screes. Since the island lacks mammalian predators it is now the main breeding-place for the smaller seabirds. It seems the obvious place for a trial rehabilitation programme.

A small tabular rock on the east side of Santa Clara, Morro Spartán, which has remained inaccessible to herbivores despite being linked to the main island by a boulderbeach at low tide, still holds the endangered cabbage trees Dendroseris litoralis and D. pruinata and Santa Clara endemic Chenopodium sanctae-clarae. Some small, steep stacks around the main island, El Verdugo in the east, Los Chamelos in the south, and the Morro Juanango in the north-west, also hold a few native plants. Unfortunately, rabbits have also been introduced to the best of them, the tiny sloping Morro Viñillo in the south-west, although like the others it still has some breeding seabirds.

\section{Isla Alejandro Selkirk}

Alejandro Selkirk is the youngest island in the archipelago, being only 1.0-2.4 million years old, lying $182 \mathrm{~km}$ west of the Robinson Crusoe group. It still consists of a great oval dome 85 $\mathrm{sq} \mathrm{km}$ in area rising to the $1380-\mathrm{m}$ peak of Los Innocentes. There is a high plateau bounded by cliffs overlooking a coastal platform in the west, and deep gorges or 'quebradas' in the east. The former luma Myrceugenia schulzei woodland on its flanks has been largely destroyed by goats, fires, a sooty mould and the insect Saissetia oleae (Meyer, 1966), and replaced on the slopes by Anthoxanthum odoratum grassland. The wetter south-western part of the high plateau is still largely covered with a native Dicksonia externa tree-fern forest. In the northern part $D$. externa is replaced by another fern, Lophosauria quadripinnata. There are some 3500-5500 brown goats (Anon., 1976), a few cattle, feral cats, rats and mice, and small numbers of alien plants. Some of 


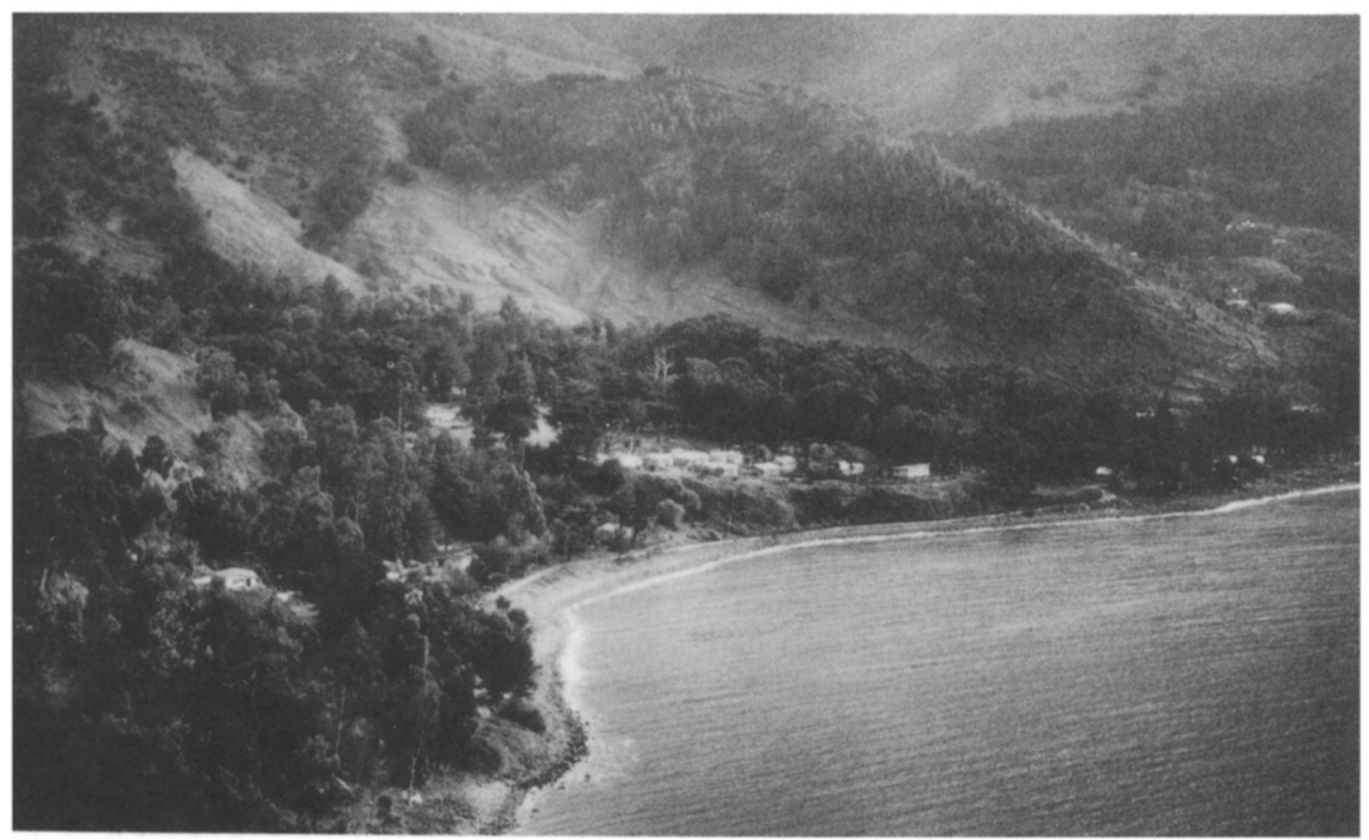

Pangal, western Cumberland Bay, Isla Robinson Crusoe, looking west. Until 250 years ago this wetter windward end of the island was covered with luxuriant endemic evergreen woodland. Old photographs show that by 100 years ago the whole area was denuded and severely eroded, as in the centre of the opposite slope. The taller vegetation now consists entirely of exotic species resistant to grazing planted since then, which are spreading rapidly (W. R. P. Bourne).

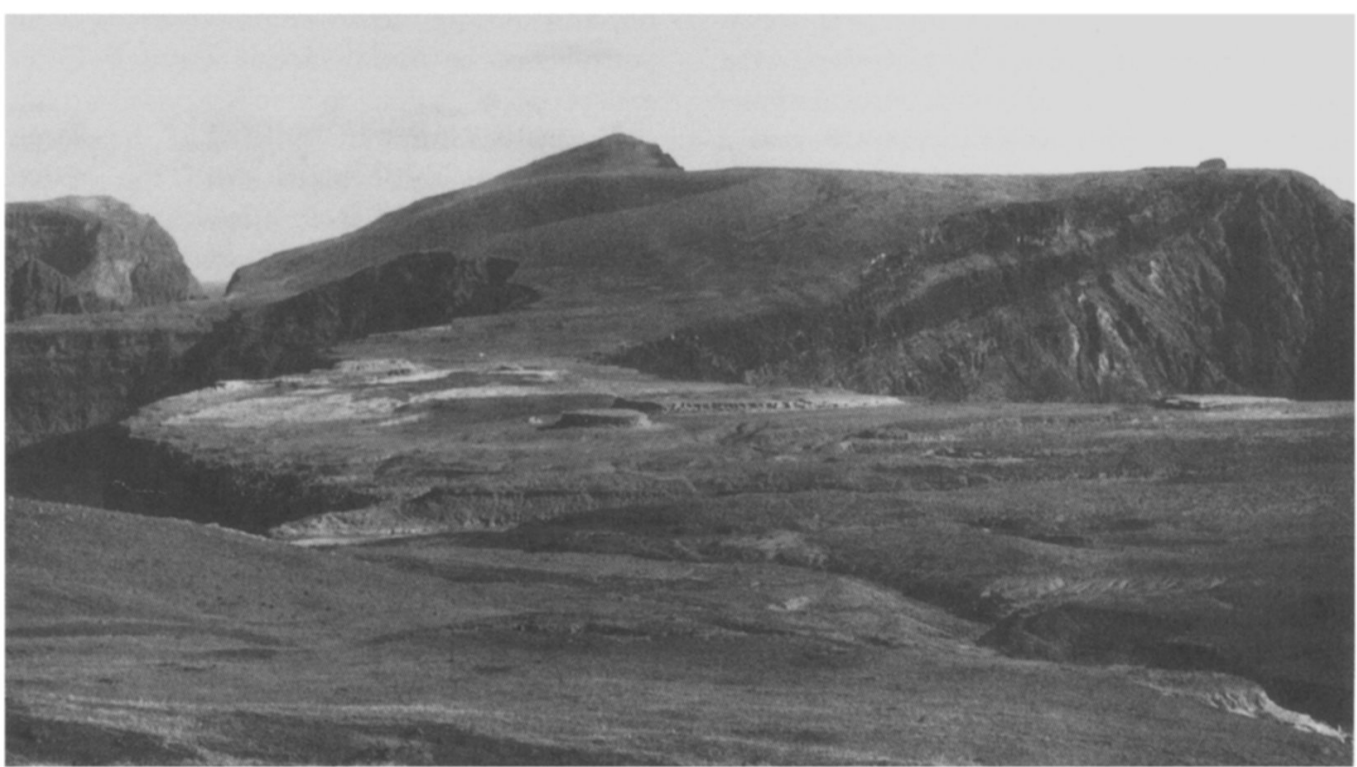

El Puente at the dry west end of Isla Robinson Crusoe. There were many seabirds whose presence doubtless led to the development of a rich endemic succulent vegetation here 160 years ago. There are now only a few old shearwater bones in the eroding dunes in the middle distance, although four species of petrel still breed on the equally over-grazed and eroded but predator-free north end of Isla Santa Clara in the upper left hand corner (W. R. P. Bourne). 
the introduced trees around the settlement at Las Casas were being cut down.

\section{The hummingbirds}

The situation of most interest, which also gives most cause for concern, involves the hummingbirds of the genus Sephanoides (Colwell, 1989). Several early visitors reported that hummingbirds were once abundant on Robinson Crusoe. In the last century the commonest was a beautiful endemic species, the 'picaflor rojo' or Juan Fernández firecrown $S$. fernandensis. This bird is very aggressive with a loud voice and, for a hummingbird, unusually marked sexual dimorphism at all ages, the male being much larger and incandescent copper all over, while the female is bright green above with a purple crown and white bib and tail markings, shown when she hovers upright in front of flowers. It would appear that, owing to overcrowding in the absence of predators and competitors, the birds have developed exaggerated territorial behaviour and sexual recognition characters.

In the minority was the smaller 'pinguerita' or green-backed firecrown S. sephanoides of the mainland, which is iridescent green above with flecked greyish-white underparts and a shimmering copper crown in the male. This has now become more numerous. A doubtful local race of the Juan Fernández firecrown, with less well-defined markings, was also found alone on Alejandro Selkirk, where it may have been affected by the decline of the woodland, since it has not been recorded since 1908, although there is a slight chance that it might still survive in the inaccessible Quebrada Guatan in the west, which still holds some unspoilt forest. A CONAF ranger, Bernardo Lopez, reported that the greenbacked firecrown first appeared at the settlement on this island in 1981, and it has now become widespread there.

Concern was first expressed about the status of the Juan Fernández firecrown on Robinson Crusoe as well after a visit in 1965 by Muñoz Pizarro (1969), who reported that they were being 'devastated' by the omnivorous intro- duced coatis, South American representatives of raccoons, which wander round the island in family parties. In 1973 Colwell (1989) also found that while the green-backed firecrown was increasingly numerous, the Juan Fernández firecrown was becoming scarce. There may now be only a few hundred birds left (Brooke, 1987a; Stone et al., 1990).

The position is still difficult to interpret. In the past the Juan Fernández firecrown was reported to build its nest in vulnerable low sites attached to the native fern Blechnum schotti. One old nest found by Brooke (1987a) in January 1986 was $2 \mathrm{~m}$ above the ground in an endemic luma Notomyrcia fernandeziana, and on 4 October 1988 Stone was shown another by a CONAF ranger, Guillermo Arroya, the first nest in use seen for 15 years, which was also entwined in the supple, leafy, outer branches of a luma $3 \mathrm{~m}$ above the ground in native woodland east of the Mirador. It consisted of a cup about $5 \mathrm{~cm}$ in diameter and $4 \mathrm{~cm}$ deep, constructed of moss and lichen with strands of material hanging down. The female incubated the two white eggs and defended the nest raucously, hovering and darting at intruders, while the male patrolled a territorial circuit about $5-10 \mathrm{~m}$ away.

The native hummingbird, which has large legs, presumably evolved with the native plants, pollinating their flowers, some of which, such as Dendroseris litoralis and $D$. macrantha, have developed perches so that the bird need not hover in the high local winds ( $T$. F. Stuessy and F. G. Stiles in Colwell, 1989). It is possible that changes in the flora caused by introduced herbivores and alien plants may have affected the balance between the hummingbirds. A CONAF biologist, Javiera Meza, is investigating their food supply throughout the year to see if there are seasons with a shortage of nectar when competition between the two species might become important.

\section{The pink-footed shearwater}

All the early visitors report that Robinson Crusoe once held vast numbers of a grey 
seabird the size of a chicken, the 'pardela', which cried 'be quiet' from holes in the slopes at night and went out to sea to fish by day, becoming 'torpid' so that it was no longer seen in the winter. It was attacked by the 'mastiffs' introduced in the seventeenth century, and was becoming restricted to the remoter upper levels and western extremity of the island, where we found its bones, by the $1820 \mathrm{~s}$ (Morrell, 1832). Together with the other large petrels it was confused with the southern fulmar Fulmarus glacialoides, which also occurs as a winter visitor, until it was eventually identified as the pink-footed shearwater Puffinus (carneipes) creatopus, which migrates north up the west coast of the Americas to winter in the North Pacific.

It was said that until a few years ago there were burrows scattered throughout the eastern mountain woodland. They are now reduced to a few thousand between $150-300 \mathrm{~m}$ on the bare, eroded, north-east slopes between Centinella and Puerto Frances, with a few hundred in Vaqueria and only isolated holes elsewhere. There were many bones scattered around, and on 24 December 1982 Roger Perry (in litt.) saw over 30 birds, which had been killed the previous night by a coati above Puerto Frances. There are still 2000-3000 pairs on Santa Clara (Brooke, 1987a) and a few on the Morro Viñilla, where there are no mammalian predators. It is still fairly common at sea and perhaps it is more successful at the only other known colony, on Mocha Island off the coast of Chile (Murphy, 1936).

\section{Seals}

Early visitors agree that the islands originally held small numbers of the southern elephant seal, which was soon exterminated, and enormous numbers of a fur seal also found on the Desventuradas Islets to the north, which can hardly have found sufficient food locally, so they may have dispersed to feed along the Humboldt Current. Thus, Alexander Selkirk reported that they were so numerous on Isla Robinson Crusoe in the early eighteenth century that they extended inland a stone's throw

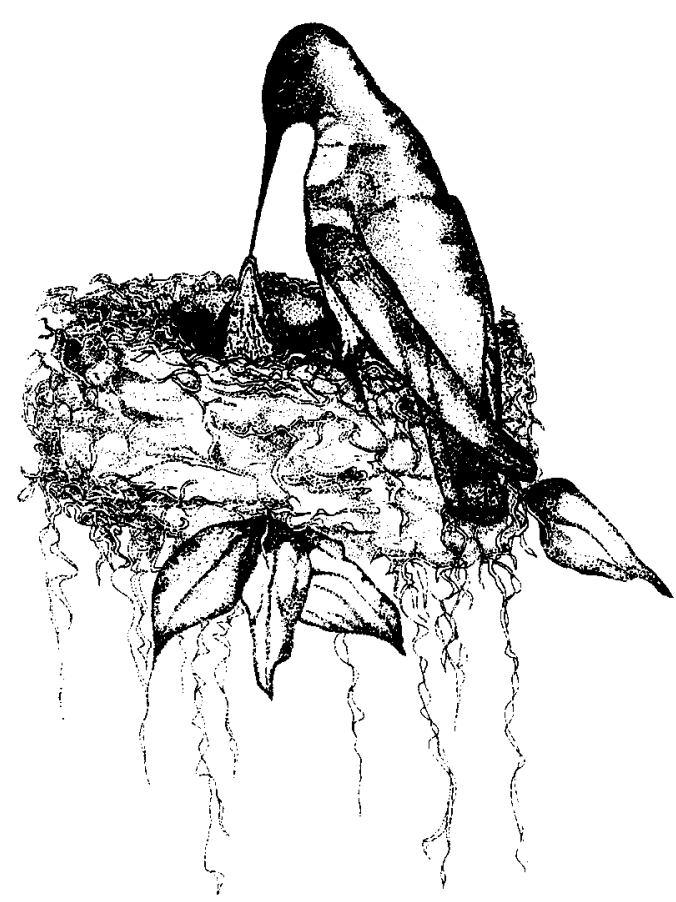

A female Juan Fernández firecrown or 'picaflor rojo' Sephanoides fernandensis, feeding a chick at the nest (drawing by T. Stone).

from the beach, which implies a population of the order of five or six figures. Yet few are known to have been killed on this island and it seems questionable whether they were exterminated early by people who left no records, or disturbed so much when the island was fortified in the 1760 s that they moved to Alejandro Selkirk.

Whatever happened on Robinson Crusoe, once sealskins were found to be the most profitable article to trade with China at the end of the eighteenth century, the western coastal platforms of 'Massaferro' proved to be one of the best sources. The numbers taken were said to 'astronomical' (Thornback and Jenkins, 1981). Morrell (1832) gave the total as 3.5 million between 1793 and 1807, with 50 left in the 1870 s. However, records kept in the monopoly market at Canton (Corning, 1944) indicate that the annual harvest for the whole world at the height of the trade barely reached six figures, so it is possible that this total may have been exaggerated, or Massaferro credited with 
many skins obtained by the secretive sealers elsewhere.

In any case it would appear that a population of this large, tame, harmless animal, possibly numbering millions in the eighteenth century, was then rapidly reduced to a few score, with a renewal of the slaughter whenever it increased again. Eventually it was concluded by much of the scientific world (although not by the local fishermen) that it must be extinct, until Professor Nibaldo Bahamonde and others reported its survival in the 1960s. Since then their numbers have increased briskly following protection (Anon., 1983) and they already numbered 8000 once more in 1988.

\section{Conclusion}

While the damage to the wildlife of the Juan Fernández archipelago is serious, so far only the loss of the native sandalwoods seems irreversible. But there is little time remaining to prevent irreparable devastation. Although it has been proposed to turn Isla Robinson Crusoe into an offshore holiday or commercial centre, so far there have been insufficient resources to complete the road from the still primitive earth airstrip in the west over or beneath the historic 'Mirador' on the ridge where Alexander Selkirk once watched the empty horizon to San Juan Bautista. However, even the early phases of construction of the road have already led to severe erosion.

If the islands are to retain their natural attractions, urgent measures need to be taken to assist CONAF to preserve them. The tame and accessible Juan Fernández firecrown may not only be Chile's most beautiful, but also its most threatened vertebrate, and its decline may be due to a reduction of the remarkable endemic flowers upon which it once fed. The young fur seals are also curious and attractive beasts, which now once again come within a few metres of visitors around Robinson Crusoe. Some of the native petrels are also unusually tame and handsome and will visit their nests close to observers by day, while the arrival of the remainder in shrieking hordes at night forms a remarkable spectacle. But all remain extremely vulnerable.

Chile is a large country with many other natural assets also in need of conservation. While she has already done much to assess the problems on Juan Fernández, there are limits to the national resources available to deal with them. This is a site of international importance and it seems time that more assistance was provided to help eliminate the introduced plants and animals and restore the native wildlife. This could start with the removal of the cattle as soon as money becomes available, and then the coatis, cats, rabbits, rats, palqui, brambles and maquis. The sum required, possibly a few thousand dollars down and $\$ 50,000$ a year (10 men at $\$ 5000$ p.a.) for 10 years, is not enormous, and might transform the islands into a key centre where tourists from all over South America could observe the results of active nature conservation.

\section{Acknowledgments}

We have all been encouraged and assisted by the courteous and helpful staff of the Chilean Corporacion Nacional Forestal, including Alfonso Glade, Carlos Weber, Jürgen Rottman, Gaston Gonzales, Ivan Leiva and the Park Guards. The Totorore Expedition was given a grant by the British Ornithologists' Union and assistance by the Armada de Chile and A. J. Broom y Cía (Valparaiso). Brooke received grants from the International Council for Bird Preservation, Fauna and Flora Preservation Society, World Wide Fund for Nature (UK) and Percy Sladen Memorial Fund, and assistance from the Chilean/American Botanical Expedition under Tod Stuessy and others listed in Brooke (1987a). The Oxford University Sin-k-Tam '88 Expedition received grants from the Royal Geographical and British Ecological Societies, Oxford University Chest Trusts, New York Explorers Club and German Hummingbird Society, and advice from Graham Stone and (about rabbit control) John Ross.

\section{References}

Allan, D. 1985. Threatened 'Protected Natural Areas' of the world. Environ. Conserv. 12, 76-77.

Anon. 1976. Plan de manajo Parque Nacional Juan Fernández. Documento Técnico de Trabajo No. 22. Projecto FAO/RLAT/TF199 Projecto PNUD/ FAO/RLA/72/028 Corporacion Nacional 
Forestal/FAO Latin American Regional Office, Santiago.

Anon. 1982. Estudio de los recursos fisicos archipielago Juan Fernández. Informe No. 45, Valparaiso. Secretaria regional de planificacion y coordinacion de la region de Valparaiso (SERPLAC).

Anon. 1983. El Lobo Fino de Juan Fernández. Chile Forestal, 8 (91), 20-22.

Arana, P. (ed). 1985. Investigaciones marinas en el Archipielago de Juan Fernández. Universidad Católica de Valparaiso, Valparaiso.

Bourne, W.R.P. 1983a. Preliminary Report on the Ornithological Situation at Juan Fernández. Unpublished report to ICBP, Cambridge.

Bourne, W.R.P. 1983b. New Zealand ornithological survey of Juan Fernández, South Pacific. Ibis, 125, 595.

Brooke, M. de L. 1987a. The birds of the Juan Fernández Islands, Chile. ICBP Study Rep. 16, 1-50.

Brooke, M. de L. $1987 \mathrm{~b}$. Population estimates and breeding biology of the petrels Pterodroma externa and $P$. longirostris on Isla Alejandro Selkirk, Juan Fernández Archipelago. Condor, 89, 581-586.

Brooke, M. de L. 1988. Distribution and numbers of the Masafuera Rayadito Aphrastura masafuerae on Isla Alejandro Selkirk, Juan Fernández archipelago, Chile. Bull. Brit. Orn. Cl. 108, 4-9.

Clark, G. 1988. The Totorore Voyage. Century Hutchinson, London.

Colwell, R.K. 1989. Hummingbirds of the Juan Fernández Islands: natural history, evolution and population status. Ibis, 131, 348-366.

Corning, H. 1944. The letters of Sullivan Dorr. Proc. Mass. Hist. Soc. 67, 178-364.

Johnson, A.W. and Goodall, J.O. 1965-1972. The Birds of Chile and Adjacent Regions of Argentina, Bolivia and Peru. 3 vols., Platt, Buenos Aires.

Kunkel, G. 1968. Robinson Crusoe's Island. Pacific Disc. 21, 1-8.

Kuschel, G. 1961. Composition and relationship of the terrestrial faunas of Easter, Juan Fernández, Desventuradas and Galápagos Islands. Occ. Pap. Cal. Acad. Sci. 44, 79-95.

Meyer, F. 1966. Chile-United States botanical expedition to Juan Fernández Islands, 1965. Ant. J. US, 1, 238-242.

Morrell, B. 1832. A Narrative of Four Voyages to the South Seas: From the year 1822 to 1831 . L. \& J. Harper, New York.

Muñoz Pizarro, C. 1969. El Archipielago de Juan
Fernández y la conservación de sus recursos naturales renovables. Bol. Acad. Ciencias Instituto de Chile, 1 (2), 83-103 (reprinted in Mus. Nac. Hist. Nat (Santiago, Chile) Serie Educativa, 9, 17-69, 1974).

Murphy, R.C. 1936. Oceanic Birds of South America. 2 vols. American Museum of Natural History, New York.

Oehrens, E. and Garrido, N 1985. On the possibility of biological control of wild blackberry in the Juan Fernández archipelago, Pacific Ocean. Boletin Sociedad Biológica de Consepción, 57, 205-206.

Perry, R. 1984. Juan Fernández Islands: A Unique Botanical Heritage. Environ. Conserv. 11, 72-76.

Saiz, G.F. 1982. Proposicion de un metodo de control integrado del conejo en el archippeilago de Juan Fernández. Universidad Católica de Valparaiso.

Sandars, R.W., Stuessy, T.F. and Marticorema, C. 1982. Recent changes in the flora of the Juan Fernández Islands, Chile. Taxon, 31, 284-289.

Skottsberg, C. (ed) 1920-1956. The Natural History of Juan Fernández and Easter Island. 3 vols., pp. 1-688, Almquist \& Wiksells Boktrycheri-A-B, Uppsala.

Stone, T., Roberts, P. and Chisholm, A. 1990. Sin- $k$ Tam '88, an Oxford University Expedition to Chile. Final Report, 35 pp. Copies deposited with: Royal Geographical Society, London; International Council for Bird Preservation, Cambridge; Oxford University Exploration Club; and Edward Grey Institute, Oxford.

Stuessy, T.F., Foland, K.A., Sutter, J.F., Sandars, R.W. and Silva, O.M. 1984. Botanical and geological significance of potassium-argon dates from the Juan Fernández islands. Science, 225, 49-51.

Thornback, J. and Jenkins, M. 1981. Juan Fernández fur seal. The IUCN Mammal Red Data Book, Part 1. IUCN, Gland, 403-405.

Woodward, R.L. Jr. 1969. Robinson Crusoe's Island: a History of the Juan Fernández Islands. Univ. N. Carolina Press, Chapel Hill, N. Carolina.

W.R.P. Bourne, Department of Zoology, University of Aberdeen, Tillydrone Avenue, Aberdeen AB9 2TN, UK.

M. de L. Brooke, Department of Zoology, University of Cambridge, Downing Street, Cambridge CB2 3EJ, UK.

G. S. Clark, Homelands Organic Orchard, Kemp Road, Kerikeri, New Zealand.

T. Stone, 33a Oxford Road, Old Marston, Oxford OX3 OPQ, UK. 